\begin{tabular}{c} 
Volume and Issues Obtainable at Center for Sustainability Research and Consultancy \\
Journal of Accounting and Finance in Emerging Economies \\
ISSN: 2519-0318 ISSN (E) 2518-8488 \\
Volume 6: Issue 1 March 2020 \\
CSRᄃ \\
Journal homepage: www.publishing.globalcsrc.org/jafee \\
\hline
\end{tabular}

\title{
The Curve of Cross Border Cartel Enforcement (Challenges and Remedies in Global Business Environment)
}

\author{
${ }^{1}$ Shahzada Aamir Mushtaq, ${ }^{2}$ Fraz Ashraf Khan \\ ${ }^{1}$ Ph.D Scholar at School of Law and Economics, Zhengzhou University, Henan, Mainland China: \\ aamir.adv@gs.zzu.edu.cn \\ ${ }^{2}$ Assistant Professor, University of the Punjab, Jhelum Campus, Pakistan: frazashraf@pujc.edu.pk
}

\begin{tabular}{|c|c|}
\hline ARTICLE DETAILS & ABSTRACT \\
\hline $\begin{array}{l}\text { History } \\
\text { Revised format: February } 2020 \\
\text { Available Online: March } 2020\end{array}$ & $\begin{array}{l}\text { The purpose of this article stated that the global economic arena has taken } \\
\text { new insights across the shore of nations. THE new economic challenges } \\
\text { are waiting for the anti-trust enforcers to make sure strict compliance with } \\
\text { the antitrust laws and in addition this dissertational work highlights the }\end{array}$ \\
\hline $\begin{array}{l}\text { Keywords } \\
\text { Cartels, Economic Effects, } \\
\text { Extraterritorial Jurisdiction, } \\
\text { Evidence Gathering, Relevant } \\
\text { Market }\end{array}$ & $\begin{array}{l}\text { incipient violations across the borders and suggests its possible legel } \\
\text { outcoms in the near future in order to make the economic market a level } \\
\text { playing field for any business entrants. It particularly shed light on the } \\
\text { cross border cartels and their effects on the relevant market, additionally } \\
\text { we have taken the global view of the legislative aspects along with their } \\
\text { de jure appliances and improvements for the proper economic growth }\end{array}$ \\
\hline $\begin{array}{l}\text { JEL Classification: } \\
D 49, H 23, L 11\end{array}$ & $\begin{array}{l}\text { under the auspices of legal framework. The ramification of cross border } \\
\text { cartel enforcement has surfaced astoundingly between } 1998 \text { to } 2015 \text {, } \\
\text { underlining the earnest and prompt action to strengthen and revisit the } \\
\text { competition law enforcement tools and proficiency. The technological } \\
\text { advancements and liberalization of trade has risen significant challenges } \\
\text { which includes the enforcement of cross border cartels and mergers. The } \\
\text { globalization of corporate activities and deregulation of business markets } \\
\text { and numerous industrial sectors has endangered the theoretical foundation } \\
\text { of domestic and international competition enforcement regime. The } \\
\text { transnational anticompetitive practices like monopolization of markets, } \\
\text { collusive price fixing, vertical restraints of trade and international cartels } \\
\text { currently challenged the jurisdiction and policies of OECD, WTO, } \\
\text { UNCTAD, and ICN. This frightening situation necessarily be regularized } \\
\text { by establishing worldwide competition policy and globally admirable } \\
\text { enforcement standard. The weaknesses of unilateral, bilateral, and } \\
\text { multilateral compacts be re-examined in order to cope with the cross- } \\
\text { border competition challenges efficaciously. The extraterritorial, } \\
\text { jurisdictional, and investigative mechanisms could be enclosed with } \\
\text { binding nature of legal structures to deter cross border antitrust violations } \\
\text { for smooth economic growth. The EU and US actively pursuing to } \\
\text { establish the unanimous international antitrust regime instead of } \\
\text { discrepancies to integrate WTO and ICN being multilateral cooperation } \\
\text { forum. Currently, US, CANADA, EU, JAPAN and CHINA across the } \\
\text { globe become more engaged in international cartels evidence gathering } \\
\text { and investigations. The developments in information sharing, private } \\
\text { enforcement, follow on civil litigation, dawn raids, extraterritorial reach of } \\
\text { enforcement watchdog is yet to be established. }\end{array}$ \\
\hline
\end{tabular}


(c) 2020 The authors, under a Creative Commons Attribution-Non

Commercial 4.0

Corresponding author's email address: aamir.adv@gs.zzu.edu.cn

Recommended citation: Mushtaq, S, A. \& Khan, F. A., (2020). The Curve Of Cross Border Cartel Enforcement (Challenges and Remedies in Global Business Environment). Journal of Accounting and Finance in Emerging Economies, 6 (1), 73-86

DOI: $10.26710 /$ jafee.v6i1.1052

\section{Introduction}

A few decades ago the antitrust matters were the subject of National or Regional boundaries relying on the doctrines that the law stops at a Nation's shore, but with the passage of time the revolutions taken place in the world economies along with that the antitrust concerns have become surprisingly international. The Nations face an augmentative vista that their economies would be harmed by anticompetitive behavior that have taken place solely or in part in other jurisdictions. It is an axiomatic fact that the world has realized the pivotal role of competition law enforcement as a necessary tool to protect the welfare of consumers and maintain the integrity of free market from anti-competitive behavior of multinational enterprises. It has also been established that competition policies have not only strengthened the growth of economies but also developed this approach that a competitive economy can best be achieved by maintaining and protecting free-market. The globalized economies have transnational effects and competition law aims to regulate their business conduct by providing the level playing field to every competitor, ensure the protection of consumer rights and restrict the concentration of economic power of corporate enterprises. The need for coordination also arises from the fact that sanctions against international cartels are not synchronized. This fact reduces the incentives of cartelists to report their cartels through leniency programs, since once the cartel is discovered the party that reported the cartel might still be subject to sanctions in other jurisdictions in which it does not enjoy leniency. In fact, this situation strengthens international cartels relative to domestic ones, as cheating on them by way of reporting produces lower rewards. It is thus important to devise ways to solve these incentive problems. The current international antitrust system is largely based on unilateral enforcement whereby each jurisdiction deals, on its own, with antitrust issues surfacing at its borders. The unilateral enforcement regime is also the main source of the enforcement problems of small and of developing jurisdictions.

In 1990 only 25 jurisdictions had a competition law and 16 had antitrust enforcement agencies. The world witnessed a growth of more than 200\% in the number of competition agencies between 1990 and 2013. In the year 2013, 127 jurisdictions had a competition law body 115 of which are functioning competition enforcement authority (organization for economic co-operation and development OECD report 2014," challenges of international co-operation in competition law enforcement.")

Today approximately more the 130 countries are observing antitrust laws including the newly emerged agencies and the agencies of the under developed economies, not all the countries seem active in enforcing their competition laws especially in cases where enterprises with anti- competitive misconduct is located outside of their borders. The growing economies are becoming more interdependent and multinational enterprises and economic entities developing the tendency to mutually operate across the borders in order to accelerate the economic efficacy. The proliferation growth of antitrust agencies, competition laws across the globe and the boost of technological trade and international industrial trade which gives birth of increasingly cross border transactions raises many new challenges to the enforcement of antitrust and competition laws. The globalized era has paved the path to economic markets for anticompetitive conduct of foreign corporate sector who have brought these practices to the other regions of the world. The concept of internationalization of cross border antitrust enforcement is a reaction to this worldwide scale of anticompetitive behavior (Clarke J and Evenett SJ, 2002). 
Since 2000 to 2016, 75 new big cartels reported each year around the globe and in-spite of these astounding figures it is still believed that a various number of cross border cartels remain undetected. Those enterprises who possesses exclusive market control and involved in cross border cartels for the sake of capturing new markets and maximizing profits are resultantly causing unbearable damages to the emerging and developing economies. The astonishing effect of cross border cartels is that it directly exploiting the gross domestic product (GDP) in poorest economies and regional or national antitrust tools seems incapable to detect and penalize them due to inefficient and stagnant competition mechanisms. Furthermore, this practice in fact limiting the international trade benefits for under developed economies ensured by the various international organizations and conventions. Global cartels are now earning undue profits from worldwide commercial markets and even if they are punished in line with the internationally established codes with heavier fines would be scrimpy. Therefore, the key international organizations such as organization for economic co-operation and development (OECD), world trade organization (WTO), international competition commission (ICN), and united nations conference on trade and development (UNCTAD), are trying to encounter this common exigency arises as a result of cross border or global cartels.

The first portentous multilateral attempt was made in July 1944, at the Bretton woods conference with the ambition to take away international anti-competitive enforcement hurdles. During the postwar period the Americans department of justice took aggressive prosecution measures against international cartels but the efforts was useless due to the ineffectiveness of world efforts the United States then took unilateral measures to deter cross border cartels by the implication of its own antitrust laws extraterritorially. The leading case on the extraterritorial application of national anti- trust laws was the United States vs Aluminum Company of America.12. 148 F.2D 416(2D CIR.1945). Gradually with the passage of time the (OECD) has presented numerous nonbinding proposals to strengthen the antitrust enforcement assistance and promote harmonization respectively in 1967, 73, 79, 86, 95, 98, 2005, and 2014. It is also pertinent from the pages of history that the loss caused to developing economies by the cross-border cartels estimated was $\$ 51.1$ billion in 1997 irrespective of the undetected cartel damage and further affected the imports of under developed countries up to the extent of 4.7 percent and 0.9 percent GDP. The developed economies had also troubled and cross border hard core cartels causes' $\$ 140.8$ consumer welfare loss to established economies. Although, enthusiastic efforts have been launched by all the concerned crossnational organizations but many deficiencies still remain unsolved and fully operational mechanism required in order to deter the cross-border menace. One sound and central working body is mandatory instead of the creation of many local, regional, or international joint working committees, platforms, and mechanisms to put this challenge down and institutional reforms might be revisited to strictly address the core issues and the spirit of free competitive market and open market access will be the theme of this article.

In the year 2016, the report was prepared by the Global competition review which witnessed macrocosm of almost 200 antitrust enforcement bureau's and this is due to the accretionary anti- competitive lead dominating and harming the global economic, in the shape of mergers, price fixing and hard-core cross border cartels. Investigation and compliance of competition rule are still byzantine due to the impediment of numerous challenges. However, iron like efforts are still required to properly address these incipient challenges as a result of technological furtherance and opening up of new common markets (Daabah MM. 2010).

\section{Methodology}

The data for this research has been taken from the various websites like international competition network, OECD, UNCTAD,WTO, US department of justice, European Union, African Union, and the reports which had been published by numerous anti-trust enforcement authorities about the augmentative 
trend of the cross border cartel violations and the data has also been taken from the judicial judgments of the American and Japanese Supreme court's who ruled out new principles for the extra-territorial application of the anti-trust laws across the borders. After careful perusal of this data various results have been drawn below to analyze and unfold the legal obstacles and make economic efficiency more progressive and rapid. we have taken results from region to region and focuses mainly on the legal restraints which exists commonly at all the regions. The online journals study has also paved the way to draw some practical hypothesis.

\subsection{Cross Border Co-Operation Among Regulators}

The EU and US primarily enlightened the beaucoup bilateral agreements with Canada and japan in order to develop the potential association between agencies in the year of 1990, simultaneously, the EU also assists other countries in dealing the matters of competition concerns through free trade covenants and economic agreements. On the other hand, the US such as Israel, Brazil, Canada, Japan and Australia. The canonic objective of these agreements was to determine the path of co-operation among regulatory authorities with palatial results. These bilateral concordats gradually become the effective tools for cooperation and provides guiding principles on competition policy matters. However, these co-operative compacts results in a hodgepodge of principles and therefore produce ambiguities and anomalousness for the antitrust watchdogs and corporate executives. Another obstacle for the developing economies was the problem to adopt which enforcement modal for the efficacious economic growth and controlling mechanism for their enforcement authorities (Lake, D. A. 2010). The outcomes of the bilateral, regional, and national compacts seeks the necessity of multilateral harmonization of co-operation on hard core cartels.

After the EU and US the other major move commence by the OECD in the form of recommendations on competition plan observance since the 1960s. Legion committees within the framework of the organization have bring forth a volume of findings and recommendations on multiple aspects of enforcement plans over the decades such as systematic cooperation among its members, the sharing of information involved in hard core cross border cartels and uniformity of procedures etc. all the four reports of the OECD respectively 1995, 1998, 2005, and 2014, chiefly focuses on the issues of anti-cartel actions with the enhancement of corporate fines, public awareness programs about cross border menace, trenchant sanctions against cartel demeanor, and multinational cooperation in investigation.

Another platform which bring forth the proposals for the efficacious implication of antitrust enforcement round the globe is UNCTAD. This was the attempt to fill the vacuum left by the predecessor organization. It was the transition periods in the world economy and the tendency was shifted from developed to developing economy. In order to deter anti-cartel conduct more effectively worldwide (Sokol, D. D. 2007). In the 1980, the UNCTAD embrace the statute on restrictive business practices which includes best practices guidelines for multinational enterprises taking on board the markets of under developed countries. After these developments which has not completely taken place yet the scholars move forward to establish other organs in the form of GATT/WTO.

Furthermore, a new statute was namely the Draft international Anti-Trust Code (DIAC) bring in by the joint working group comprised of the European, Japanese, and German scholars with the intention to merge some competition touchstone to the GATT and then to be implemented at the national levels for howling progress, but it was vehemently opposed by US scholars and anti-trust policy makers (Hartzenberg T, 2016).

The speedy and inevitable ontogeny of hard core cross border cartels lead the US to follow up on other ways of co-operation and transnational enforcement resultantly international competition policy advisory committee was formed in 1997, to revisit the anti-trust and enforcement challenges which in its report 
charge the WTO to be a malapropos and advise the origination of "Global competition initiative" which in 2001 paved the way for the instauration of international competition network( ICN).

In spite of all these thought-provoking developments the challenge to deter the cross-border cartels has not been cemented yet, but the approaches keep changing now recently in 2018 the Singapore's antitrust authority has found five Japanese and local enterprises guilty in fixing the prices and other transnational cartel engagements and proceed to fine four companies out of five with a total cost 19.5 million Singapore dollars which amounts to $\$ 14.8$ million. It is also noted that like investigations are afoot in South Korea and China, and concluded that the authority is working in line with similitude of EU, US and Japan. This case was presumed to be the high profile and exemplary for the enforcement agencies currently working on across border cartels.

\subsection{Information Exchange Phenomena}

The enlargement of the network industry, service sector, the incipient growth of the technology and maturation of the digital economy has a sarcastic impact on conventional industry, exacting the involvement of expeditious exchange of information among the operative enforcement institutions. The huge impediment in the way to dissuade cross border cartels is the deficiency to exchange the relevant information among global antitrust watchdogs, although attempts has been made to enlarge the cooperation and information of the transnational violations but the barriers has not been removed. The different nature of the domestic and international codes further aggravated the situation because lack of trust exists between developed and newly surfaced enforcement agencies (Burney, A., Abbas, Z., Mahmood, N., \& Arifeen, Q. U. 2013). There is no binding statutes globally in respect of the information sharing mechanism. The UNCTAD defines some pattern of information co-operation taking into account the principles of mutual trust, good will, and a thirst to work jointly (Byrne, A., \& Fitzpatrick, Ú. 2009). The concept of exchange of information and sweetening the co-operation between members has always remain key agenda and central point of discussion but how this challenge could be tackled has not been addressed with contemplative thought.

The uniformity and unanimous consensus to share the information involving cross border violations is severely lacked at transnational and regional level because of jurisdictional discrepancies. It is considered to be the chief component which lacks consentaneous approach. The enforcement agencies of UK, Canada, US, China and Australia majorly concentrating on the new investigative tools and established mechanism for exchange of information including the confidential information in order to aggressively deter the cross-border cartels and to lessen their concentration of economic power by the use of unlawful means (Singh, V. K. 2017). Now it is the time that OECD, WTO, ICN, and UNCTAD to make some binding regulations for the member states and for regional enforcement authorities to address the crossborder issues that surpass beyond their jurisdictions. The latest development which has taken place in Japan is exemplum for the rest of the global enforcement agencies regarding the sharing of information and booming the co-operation with other antitrust regulators of the world.

The Japan modal categorized the transnational antitrust co-operation compacts into two parts for impelling cooperation across the globe. The first part includes the agreements between states for exchanging the published information and the second part deals with the covenants of sharing confidential information. Japan's most antitrust agreements about mutual cooperation with the mature enforcement agencies like Australia, Canada falls within the domain of the first category. The step was initiated by Japan in 2015, and upgraded in 2017 respectively because of changing economic trends. The WTO and ICN could adopt this kind of model for effective mutual cooperation and quicken the ability of under developed economies to respond the wrongdoings done by the corporate executives. The second proposed part (which includes the sharing of confidential information) has pivotal importance and needs the equal confidence and trust level between all competition agencies developed and developing. This part is 
sensitive in nature because mature agencies perceived the performance of newly surfaced competition authorities to be the house of cards (Hartzenberg T, et. el.)

If Japan succeeds in signing the treaties with the European and Asian countries regarding the exchange of confidential information what would be its effects on the developing economies and this question will remain the matter of grave concern for the globally functioning antitrust enforcement watchdogs. Japan had also entered into an agreement with the US in 2010 after amending its antitrust law and augmented the provision of information gateway in order to enabling the new competition enforcers to take the advantage and increased cross border performance. Therefore, the business and legal fraternity has also raised its reservations against the sharing of confidential information and the legal practitioners demanded the legislation to protect the communication between the attorney and client which is their legal right recognized by the legal world.

\subsection{Increment of Cross Border Cartel Violations}

The staggering increment in technological and industrial advancements, rapid growth of trade liberalization and opening up of new economic horizons the apprehension of mal-business practices prevails which causes economic crunch and need to be dealt with strict regulations and the wave of competition and antitrust codes aims to serve this purpose. The birth of domestic, regional, and international enforcement watchdogs is an attempt to protect the economic market and make it better and more spellbinding for all the business competitors in the relevant market. The catching of cartels and anticompetitive practice is a core challenge tackling by competition bureau's around the world. Various cross border cartel detection inquiries are in the pipelines in Europe, Australia, US, Japan, China and South Korea.

The important instrument which is using by almost all the enforcement authorities is the doctrine of leniency which is very recently launched by the mature and newly developed competition regimes. Leniency is proving influential in catching the both domestic and cross border hard core cartels but its nature and application varies from jurisdiction to jurisdiction and region to region which is another challenge for the champions of antitrust law makers. International organizations and regional competition enforcers technically assisting the domestic competition watchdogs in several jurisdictions. To detect the cross border cartels only leniency instrument seems to be inadequate. The stupefying fact is that in whole Africa there is no suffice leniency plans due to the lack of proper reward schemes to the informants which again evidenced the complexity of the application of leniency doctrine.

It seems to be the greater challenge for the competition watchdogs to establish unanimous universal instrument to deter cross border cartels. However, this problem up to some extent but not completely be monitored and controlled by making the regional enforcement agencies full operational aiding with some binding set of laws for the member states. This exercise will upgrade the potential and capability of the regional institutions (Republic of Arg. v. Weltover, Inc.1992). In 2018 a big cross border cartel case has been caught by the Singapore's antitrust watchdog in which five electronic parts maker companies of Japan in collaboration with local businessman founds guilty to be involved in price fixing and malbusiness practices.

\subsection{Dynamic Nature Of Antitrust Enforcement And Modern Challenges}

To address the nascent challenges and enforcement of antitrust laws across the nation is still a complex phenomenon, the US and EU antitrust theories not have the same traits in numerous ways. They have diametric institutional and procedural fabrics. The aftershocks of Brexit jeopardize the instance of EU that have favored competitive market and trade liberalization. We can analyze the different nature of antitrust enforcement procedures adopted by the EU and US recently in the high-profile cases against Google, Microsoft, Amazon, Facebook, and Apple apps. The FTC stopped its investigation against Google but EU has fined the Google with the penalty of $\$ 1.49$ billion for misusing its dominant position in the market, 
and that is not for the first time that Google has been fined it is approximately more than six (6) times up till now and unpredictable about the future. The act of Google was found harmful for online business and advertisements by excluding the other competitors from the market such as Microsoft and Yahoo (Dann, G. E., \& Haddow, N. 2008).

The German Federal Cartel Office ban the use of data gathered by the Facebook without the express consent of the consumers and that is extra-ordinary development against technology tycoons. The ongoing debate on this recent development taken by the German FCO within other mature enforcement agencies is very thought provoking, whether it will have extraterritorial effects in the long run or not? (Sokol, D. D., \& Comerford, R. 2015). Since the last 125 years, the United States uninterruptedly observing the three-fold enforcement procedures in order to scrap anti-competitive practices under the domain of federal, state level, and private enforcement. The US has a long history of antitrust law (THE SHARMAN ACT,1890) than any other country on the map and has also relying on the above stated three modes of enforcement. The common law approach was followed by the US Congress at the time of framing antitrust laws in order to discourage the socially undesirable business conduct. The history of antitrust legislation renders the primary description of the destination which US Congress assay to advance, competition and free market, and left the room empty for further development through the judicial interpretation. The reason was that in middle ages the most common law was originated through judicial precedents so same was the case with the development of the antitrust law (Gutiérrez, G., \& Philippon, T. 2018).

In the US different measures were adopted through different institutions to enforce the antitrust laws. The FTC and US Department of justice are liable to guarantee the compliance of antitrust laws and to protect the market and consumers from any highhandedness of the corporate executives. The private enforcement is rapidly increased in recent years in which the individuals can seek damages from the wrongdoers for antitrust harms with the assistance of attorneys. The public and private enforcement of antitrust statutes has become core issue now, some jurisdictions are following both approaches for antitrust enforcement like US while some other are relying on private enforcement procedure like Europe. The myth of EU and US antitrust laws has been same but nature of enforcement varies which further aggravated the situation and puts the developing economies on the horns of dilemma.

The US justice department has been empowered to enforce the Sharman Act, 1890 both civilly and criminally, the justice department has the coercive investigative instruments which the private enforcement sector lacks in its body and can only file civil suits for damages to recover the loss suffered by them due to the harmful business conduct. This strength of the US justice department enables him to unveil and prosecute the cartels at the national level. Moreover, the federal competition law is applicable to local cartels only when the harmful conduct has a strong nexus to interstate trade. The investigation of the local cartels is beyond the jurisdiction of the justice department and only concerned states have been authorizes to initiate civil suits for losses instead of criminal prosecution.

The three cartel enforcement procedures followed by the US at the federal level (under the authority of justice department and FTC) at state level through private enforcement (civil suits) symbolizes the decentralization of enforcement measures. In Europe the competition enforcement regulation 2003 revised in 2006 also depicts the same formula for cartels enforcement. Under the European competition enforcement mechanism, the power has been delegated to 26-member states to investigate the cartels at national level following the guidelines contained by the Europe's competition regulation 2006. In the US the federal trade commission (FTC) has also been delegated the powers under section 5 of the federal trade commission act to investigate and prosecute the cartels civilly (Motorola Mobility LLC $\mathrm{v}$ AU Optronics Corp). 
The parallel jurisdiction of two departments invites complex procedural issues but in Europe institutional conflict of procedural enforcement between member states and commission is very limited but not exclusively absent. It is noteworthy that article 3 of the European Regulation 2003 empowers national competition authorities and including their courts to apply articles 81, and 82 to those compacts, judgments, or conduct that poignant trade among member states. In the present circumstances several are worried that the process of decentralization for cartel enforcement in both EC and US will establish the renationalization of competition regime and again global dream will remain in darkness. No doubt that presently the increasing growth of private enforcement has attractive potential which lessens the governmental labor in deterring the cartels and collecting the evidences but all aspects of private enforcement is not encourage able due to the poorly designed scheme.

The OECD since the last two decades actively playing its leading role in providing the guidelines and recommendations across the nations to meet the challenges. In 1995, the OECD recognizes that the competition authorities can enjoy only limited powers in respect of cooperation and this practice still prevails globally. The hard-core cartels were first defined by OECD in the recommendations of 1998, and condemned it. It was also outlined that member countries ensure the effective enforcement of competition laws in detecting the hard-core cartels and sets forth the principles to protect common interest and cooperation in precluding hard core cartels. The further development was made by the OECD in 2005, stresses the establishment of globally recognized principles of best business practices. The recommendations also specifically deal the cooperation with respect to cross border cartel and merger cases and reduced inconsistencies. Again in 2013 the OECD and ICN (international competition network) had issued a report which witnessed that cooperation level between different jurisdictions was very vulnerable due to some domestic or regional legal constraints. In 2014, the OECD proposed revised recommendations which contains two important developments namely the adoption of the provisions at domestic level to exchange confidential information without the consent of the informant and heighten the cooperation with respect of investigation assistance. Finally, in 2017 at Paris the OECD roundtable debate was held to counter the challenges surfaced because of interdependence of market economies. The latest challenge was how to redress the domestic competition harm occurred in other jurisdictions and the infliction of transnational remedies, and to draw the line of action that how enforcement agencies deal the cross-border cartels (US Department of Justice, 2000).

Table.1: Comparative view of antitrust provisions

\begin{tabular}{|c|c|c|}
\hline USA & China & Europe \\
\hline $\begin{array}{l}\text { The Sharman Act } 1890 \\
\text { Section } 1 \text { prohibits contracts, } \\
\text { combinations, and conspiracies } \\
\text { that unreasonably restrain trade. } \\
\text { "It is now understood that firms } \\
\text { are in violation of Section } 1 \\
\text { when there is an agreement } \\
\text { among competitors to limit } \\
\text { competition. "Every contract, } \\
\text { combination in the form of trust } \\
\text { or otherwise, or conspiracy, in } \\
\text { restraint of trade or commerce } \\
\text { among the several States, or with } \\
\text { foreign nations, is declared to be } \\
\text { illegal." } \\
\text { Section, } 2 \text { Monopolizing trade a }\end{array}$ & 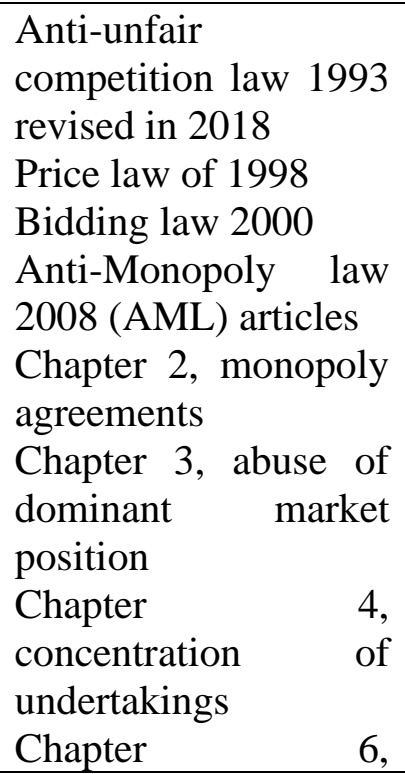 & $\begin{array}{l}\text { The Treaty of Rome } 1957 \\
\text { Establishment of } \\
\text { European Economic } \\
\text { Community (EEC) } \\
\text { Creation of European } \\
\text { commission (EC) } 1992 \\
\text { Articles of the treaty } \\
\text { Harmonious development } \\
\text { of economic activities } \\
\text { Competition in common } \\
\text { market not distorted } \\
82,82 \text {. Rules dealing with } \\
\text { anticompetitive agreement } \\
83,89 \text {, 85. Deals with } \\
\text { enforcement } \\
\text { Article } 101 \text { (1) of the }\end{array}$ \\
\hline
\end{tabular}




\begin{tabular}{|c|c|c|}
\hline $\begin{array}{l}\text { felony; } \\
\text { Section, } 3 \text { Every contract, } \\
\text { combination in form of trust or } \\
\text { otherwise, or conspiracy, } \\
\text { The Clayton Act } 1914 \\
\text { Additional prohibited conducts } \\
\text { Price discrimination } \\
\text { Exclusive dealing agreements } \\
\text { Tying agreements } \\
\text { Intends to strengthen the antitrust } \\
\text { enforcement } \\
\text { Can imposed civil penalties only } \\
\text { Enforced by antitrust division } \\
\text { and FTC } \\
\text { Federal Trade Commission Act }\end{array}$ & $\begin{array}{l}\text { investigation of the } \\
\text { suspected monopoly } \\
\text { conducts } \\
\text { Chapter } 7 \text {, article } 46 \\
\text { deals with the } \\
\text { enforcement powers } \\
\text { of the antitrust } \\
\text { authority. }\end{array}$ & $\begin{array}{l}\text { TFEU (1999) states: "The } \\
\text { following shall be } \\
\text { prohibited: all agreements } \\
\text { between undertakings, } \\
\text { decisions by associations } \\
\text { of undertakings and } \\
\text { concerted practices } \\
\text { which... have as their } \\
\text { object or effect the } \\
\text { prevention, restriction or } \\
\text { distortion of competition." } \\
\text { 102. Prohibits the abuse of } \\
\text { dominant market position }\end{array}$ \\
\hline
\end{tabular}

\subsection{The Curve Of Coordinated Efforts for Akin Investigation Process.}

The OECD is addressing the enhancement of cooperation and mechanism for sharing of information and joint investigation agendas since the last three decades. The decentralization of enforcement measures in Europe and other regions across the nation has an enthusiastic effort to determine coordinated investigation process at regional levels. The maturation trends of regional trade agreements (RTAs) between less developed and developed economies is now travelling speedily.

The UNCTAD has already submitted a report and emphasis the inclusion of the competition related provisions in the regional trade agreements and the findings proposed by the UNCTAD were discussed at various regional level seminars. The concrete objective of these findings is to improve the competition law enforcement strategies. The report also contain the key issues and highlights the effects of the inclusion of competition related provisions (CRPs) in regional trade agreements (RTAs) (US Department of Justice).

Following are some possible potential benefits of the inclusion of CRPs in RTAs.

1. It will strengthen the discouragement up shot of the national law.

2. Promote international cooperation as was suggested by WTO,ICN, etc

3. Brings potential changes in the nature, performance and status of domestic enforcement bodies.

4. To reduce the apprehension of weak competition culture.

5. Discourage the incompatible environment or practices in small markets.

6. Competition may become a concrete factor in poverty assuagement.

In the recent past, the Singapore case (in which national antitrust agency catch a foreign cartel involving local market as a result of joint investigation by Singapore and Japan) epitomize the concept of harmonious investigation started in one country lead to alike investigation in other country. This idealization of harmonious investigation at level between nations may become a powerful instrument for deterring the cross-border cartels. The potential of similar investigation process at regional level will also make the corporate sector liable to render serious cooperation with the investigative authorities. When the Singapore antitrust authority commence the investigations against the cross-border cartels that investigation was linked with the Japan's Fair-Trade Commission (JFTC). They mutually share the 
confidential information and also collected evidence then the electronic parts supplier companies Nichicon, Nippon, Ruby- con, and Chemi- con were not only punished by the competition commission of Singapore but were also fined by the FTC of Japan with the coast of 6.6 billion yen ( $\$ 62$ million) on all the five companies for violating the domestic antitrust law through fixing the price. This doctrine sets the principle for other leading enforcement authorities to follow it in their circumstances (United States Department of Justice 1996).

\subsection{The Scope of Extra-Territorial Jurisdiction of National Agency and Application of Leniency Program.}

In the last quarter of 2017 the noteworthy verdict was made by the Supreme Court of Japan giving mandatory jurisdiction to the Japan's domestic antitrust authority to go after the cross-border cartels causing harm to local market. The Supreme Court allowed the antitrust watchdog to punish the crossborder cartels if their conduct has been proved violated and affecting free and fair competition in domestic market (Campbell, A. N. 2017).

In 2010, a complaint was made to the FTC of Japan against a Malaysian unit of electronic maker (Samsung SDI) that the unit had conspired in fixing the price with other competitor's on picture tubes contrary to the anti- monopoly law of the land. The commission inflicted a fine on Samsung SDI with the liability of 1.37 billion yen (\$14.8 million). The company challenged the fine along with the jurisdiction of the Japan's FTC. The High Court upheld the fine and again it was appealed to the Supreme court of Japan. The top court passed the palatial judgment not only upheld the fine but expressly announced it that the Fair Trade Commission (FTC) has the extraterritorial jurisdiction to deter, investigate and punish the cross-border cartels if that cartels effecting the market of Japan and violates the provisions of the competition law. The judgment further said that the cartel was hitting the Japanese economic order and in that circumstances the jurisdiction of the domestic antitrust authority extends to catch it and punish it (Nam, S. S. 2018).

This principle is now following in the Europe and other regions of the world in order to obtain desired results against the complex phenomena of cross border cartels. It is also worth mentioning to elaborate here the applicability of the leniency principle which is very closely linked with all of this investigative process. If a cartel has been detected and the company subsequently applied for the leniency and fully cooperated with the investigative forces and endured not to repeat that practice should be privileged. For example, the Panasonic (an electronic devices maker company) was investigated by the Japan's FTC in 2014, and due to the company's cooperation was exempted from the fine. Again, the Panasonic recently has become the subject of investigation in Singapore and render full cooperation resultantly received full immunity from the financial sanctions.

\subsection{New Areas of Enforcement}

The economic and trade progression ingrained new areas of competition enforcement affecting cross border economies. The fifth generation is the era of technologies rivalry. The red-hot competition enforcement orbit is, online advertisements, collision in the use of algorithms, online deceptive marketing practices. The monopoly of institutional investor in purchasing shares from open market, dominance over technology, excluding competition on social networks control and usage of big data private judicial proceeding etc. The pinching fact is that most of under developed economies have not focused yet on these areas of competition enforcement and no suffice legislation has enacted yet to counter these challenges. This new gainsay bringing into existence a gap in cross border enforcement of competition laws. Regional competition platforms may render assistance and mechanism to deter these new developments in line with the competition enforcement policies (Urbanova, M. 2018).

\subsection{Confronting Challenges 1n Cross Border Enforcement}


In the present arena, the biggest challenges for antitrust enforcement are to deter the cross-border cartel and merger control. In EC, US and Japan positive developments are under process but in Asian and African countries the successful dealing in lacking. The US and Japan recently adopted the extraterritorial approach for the enforcement of anticompetitive behaviors with same limitations while Europe is also taking same measures for aggressive enforcement. The Kenyan competition act also empowers its enforcement authorities to catch cross border cartels under section 6 of the act and provides foundation in adopting the extraterritorial approach. A few new challenges has been outlined below which needs the attention of authorities for improvement.

1. Constraints in cross border evidence gathering

2. Lack of binding nature of regulations across the globe

3. Lengthy and complex procedure of investigations

4. Ramification of more than one cartel enforcement global intuitions

5. The need of efficient mechanism for information sharing

6. Conflicting jurisdiction legislations

7. Deficiency in the application of Leniency program universally

8. Inconsistency between the principles of WTO, UNCTAD and ICN

9. Clash of economic interests among nations

10. Non-imposition of criminal liability

11. Different nature of administrative and civil law procedures

12. Uncertainty of enforcement rewards scheme

\section{Proposals}

1. Adoption of unanimous Leniency programs

2. Need of evidence sharing agreements at regional or domestic level

3. Worldwide homogeneous investigative process

4. Application of binding recommendations for Member States

5. Congruent Merger Approval stipulations

\subsection{Recent Cartel Cases}

Until recently, the immense cross border cartel violations have been uncovered through investigation which includes the freight forwarding air cargo, foreign exchange rates (Forex) auto parts, Samsung SOI tire maker companies, thin film transistor liquids crystal display (TFTLCD) online wall poster scandal of Amazon, oil company petrobas, London interbank offered rates (LIBOR).

Some countries around the world such as Argentina, Singapore, Japan, Brazil and Canada have inducted cross border cartel investigations with extraterritorial implication. Most recently Mexico has also flexing its cartel enforcement brawniness because its enforcement agency has fined five transnational shippers for being involved in a cross-border price fixing scheme related to vehicle carrier services.

Jurisdictional engagement at regional or domestic level is a care challenge that which law could be applied for the enforcement of transnational cross border cartels in the presence of transnational cross of various global institutions. The US opposed the inclusion of cross border enforcement provision in the constitution of world trade order and had relied on the non-binding stator rules which would be persuasive in nature strictly, while the EU proposed the internationalized competition arena. This unprecedented nature of jurisdictional battle is main restraint toward the achievement of global goals. Although after the decentralization the enforcement concern shifted from international to regional or national level the core jurisdictional challenge has not been addressed yet for cross border enforcement, the newly surfaced challenges like data monopoly, vertical restraints exclusive mobiles app controlling power network social platforms creates new problems for the regional or national antitrust agencies and jurisdictional discrepancy has become more critical even a herculean task. 


\section{Conclusion}

Global competition regime is still developing. The establishment of regional competition Organizations is a broad step in enforcing cross-border competition challenges as it offers a number of opportunities such as enhanced cooperation and harmonization of laws. However, it still faces a myriad of challenges such as jurisdictional conflict, lack of harmonized legislations, and nature of voluntary cooperation amongst others. Taking into account that international anti-competitive conduct due to globalization, trade liberalization and technological advancement lead to transactions national or regional borders, the need to review transnational competition policy in cross border enforcement is vital. Developing countries should strengthen its national and regional regimes. Lastly, they must enhance mutual cooperation at national, regional and international level in order to aggressively deal new challenges. The United States' cooperation with antitrust enforcement authorities elsewhere in the Americas, however, is more limited. Other than Canada, the United States has executed bilateral antitrust cooperation agreements with only four American countries: Brazil, Chile, Colombia and Mexico. Only Brazil has a track record as an active cartel enforcer, and Colombia has only recently strengthened its cartel enforcement regulations and begun imposing fines of significance in cartel cases. Furthermore, these four bilateral cooperation agreements are largely toothless, mandating very little in the way of actual cooperation.

\section{References}

Burney, A., Abbas, Z., Mahmood, N., \& Arifeen, Q. U. (2013). Prospects for mobile health in Pakistan and other developing countries.

Byrne, A., \& Fitzpatrick, Ú. (2009). Bee conservation policy at the global, regional and national levels. Apidologie, 40(3), 194-210.

Campbell, A. N. (Ed.). (2017). Cartel Regulation. Law Business Research Ltd..

Clarke J and Evenett SJ, The Deterrent Effects of National Anti-Cartel Laws: Evidence from the International Vitamins Cartel (World Trade Institute 2002).

Daabah MM, International and Comparative Competition Law, (Cambridge University Press 2010).

Dann, G. E., \& Haddow, N. (2008). Just doing business or doing just business: Google, Microsoft, Yahoo! and the business of censoring China's Internet. Journal of Business Ethics, 79(3), 219-234.

Global Competition Review, Handbook of Competition Enforcement Agencies (Law Business Research Limited 2016).

Gutiérrez, G., \& Philippon, T. (2018). How EU markets became more competitive than us markets: A study of institutional drift (No. w24700). National Bureau of Economic Research.

Hartzenberg T, 'Competition Policy in Africa' in C Hermann, M Krajewski and J Terhechte, European Yearbook of International Economic Law (Springer 2012)

Lake, D. A. (2010). Rightful rules: Authority, order, and the foundations of global governance. International Studies Quarterly, 54(3), 587-613.

Memorandum of Understanding between the Antitrust Division, United Sates Department of Justice and the Immigration and Naturalization Service, United States Department of Justice (15 March 1996), available at www.justice.gov/atr/public/criminal/9951.pdf

Nam, S. S. (2018). Our Country, Right or Wrong: The FTC Act's Influence on National Silos in Antitrust Enforcement. U. Pa. J. Bus. L., 20, 210.

Republic of Arg. v. Weltover, Inc. (91-763), 504 U.S. 607 (1992).

See Brief for United States and the Federal Trade Commission as Amici Curiae in Support of Neither Party at 6, Motorola Mobility LLC v AU Optronics Corp, No. 14-8003 (7th Cir. 5 September 2014), ECF No. 92.

Singh, V. K. (2017). Failed WTO Platform for Competition Law Convergence: Evolving Alternate 
Regime of Mous on Internationalization of Competition Law. Indian Journal of International Law, 54(3), 368-394.

Sokol, D. D. (2007). Monopolists without borders: the institutional challenge of international antitrust in a global gilded age. Berkeley Bus. LJ, 4, 37.

Sokol, D. D., \& Comerford, R. (2015). Antitrust and Regulating Big Data. Geo. Mason L. Rev., $23,1129$.

Urbanova, M. (2018). Japan's Legacy of Technology in the Digital Era: A Mixed Methods Analysis of the Competitive Advantage of the IoT sector in Japan.

US Department of Justice, Antitrust Cooperation Agreements, available at www.justice.gov/atr/public/international/int-arrangements.html.

US Department of Justice, Improving Bilateral Antitrust Cooperation, Remarks by Charles S Stark at a Conference on Competition Policy in the Global Trading System: Perspectives from Japan, the United States, and the European Union at 2 (23 June 2000), available at www.justice.gov/atr/public/speeches/5075.pdf. 
